\title{
STUDY OF INHERITANCE FOR YIELD AND SOME TRAITS IN TWO BREAD WHEAT CROSSES
}

\author{
M. M. Mohamed, S.T.I. El-Sherif, A. I. Yahya \\ Wheat Research Department, Field Crops Research Institute, ARC.
}

\begin{abstract}
The present investigation was carried out at Sids Agricultural Research Station, Agricultural Research center (ARC.), Egypt, during three successive seasons of 2013-2014, 2014-2015 and 2015/2016. The objective of this study to estimate of mean performances, gene action, heterosis and inbreeding depression for grain yield and its components and characters. Six populations $\left(\mathrm{P}_{1}, \mathrm{P}_{2}, \mathrm{~F}_{1}, \mathrm{~F}_{2}, \mathrm{BC}_{1}\right.$ and $\left.\mathrm{BC}_{2}\right)$ for two crosses were used in this study coming from $\left(\mathrm{P}_{1} \times \mathrm{P}_{2}\right)$ and $(\mathrm{P} 3 \times \mathrm{P} 4)$. The estimates of the six parameters, i.e. additive (d), dominance (h), additive $x$ additive (i), additive $x$ dominance $(j)$ and dominance $x$ dominance (I) and means $(\mathrm{m})$, the mean effects were highly significant for all studied traits in the two crosses, indicating that these traits are quantitatively inherited. For heterosis, highly significant heterotic effect positive was found between crosses for 1000 kernels weight in two crosses and number of grains per spike in second cross. On the other hand inbreeding depression showed highly significant negative with first cross and positive with second cross. In general first cross was highly significant negative, but in second cross grain yield per plant, 1000 kernels weight and number of grains per spike was non-significant. In two crosses, regarding potence ratio value were more than unity for all traits under study except number of grains per spike with first cross and days to heading in second cross.
\end{abstract}

Key words: Wheat, Gene Effects, Heterosis, Inbreeding depression,

Potence ratio.

INTRODUCTION

Wheat (Triticum aestivum, L) crop is considered as one of the essential strategic cereal crops not only in Egypt, but also all over the world. In addition wheat is the world's single most important food crop in terms of tons of grain produced each year. Wheat trade represents a significant component of the trade balance of national economic. Wheat is utilized and processed for a multitude of products, reflecting the large quantities produced by people of diverse cultures and social groups (Faridi and Faubion, 1995).

Wheat breeders are interested in estimating the relative magnitude of the genetic variance and types of gene action involved in expression of characters. Therefore, they need detailed information about the nature of gene action, heterosis, potence ratio and inbreeding depression, from yield and its

Fayoum J. Agric. Res. \& Dev., Vol. 31, No.1, January, 2017 
components. These targets could be realized by breeding new high yielding, early maturing. Many investigators studied the type of gene effect in wheat and reported that dominance effect was relatively more important than additive one for grain yield, while, additive genetic effect was predominated in the expression of plant height and days to heading. Similar results were obtained by Hendawy (2003), Moussa (2010)

The choice of selection and breeding procedures for genetic improvement of any crop is largely dependent on the knowledge of type and relative amount of genetic component and the presence of non-allelic interaction for different characters in the plant materials under investigations. Knowledge of the degree of heterosis and inbreeding depression plays a decisive role towards the choice of breeding methodology. Similar results obtained by Novoselovic et al (2004) and E.I. Zaazaa and El-Hashash (2012).

The objective of the current study was to estimate gene effects, genetic advance, inbreeding depression and genetic coefficient of variation for seven traits in two bread wheat crosses by using their six populations i.e., P1, P2, F1, $\mathrm{F} 2, \mathrm{BC} 1$ and $\mathrm{BC} 2$.

\section{MATERIALS AND METHODS}

The present study was carried out at the agricultural research center (ARC), Sids Research Station, Wheat Research Department during three successive seasons of 2013-2014, 2014-2015 and 2015/2016. four bread wheat genotypes (Triticum aestivum L.) were used as parental lines. The commercial names and pedigree are presented as follows:-

Table (1): The commercial names and pedigree of the four parents of bread wheat genotypes.

\begin{tabular}{|c|l|l|}
\hline Crosses & \multicolumn{1}{|c|}{ parents } & \multicolumn{1}{c|}{ Pedigree } \\
\hline \multirow{3}{*}{ Cross I } & P1 Misr 1 & OASIS / SKAUZ // 4*BCN /3/ 2*PASTOR \\
\cline { 2 - 4 } & P2 Line 5 & HUBARA-13//ACHTAR/INRA 1764 \\
\hline \multirow{3}{*}{ Cross II } & P3 Giza 168 & MRL / BUC // SERI \\
\cline { 2 - 3 } & P4 Sids 13 & Kauz "s" // Tsi / Snb"s" \\
\hline
\end{tabular}

In the first season of 2013/2014, two crosses were made among the parents to produce $\mathrm{F} 1$ hybrid grains. The two crosses were $\mathrm{P}_{1} \times \mathrm{P}_{2}$ (cross 1) and $\mathrm{P}_{3} \times \mathrm{P}_{4}$ (Cross 2). In 2014/2015 season, some of $F_{1}$ plants for each cross were backcrossed to produce the (BC1 and $\mathrm{BC} 2)$. At the same time, some other $\mathrm{F}_{1}$ plants were selfed to produce $\mathrm{F}_{2}$ seeds and croses between parents were made to preduce $F_{1}$. In $2015 / 2016$, the six population seeds, i.e. $P_{1}, P_{2}, F_{1}, F_{2}, B_{1}$ and $\mathrm{BC}_{2}$ of the two crosses were sown in a randomized complete block design with three replications. Each plot consisted of 20 rows, i.e., eight rows for F2 seeds, two rows for each of $\mathrm{P}_{1}$ and $\mathrm{P}_{2}$ or $\mathrm{F}_{1}$ and three rows for $\mathrm{Bc}_{1}$ or $\mathrm{Bc}_{2}$. The rows were $3.0 \mathrm{~m}$ long, $30 \mathrm{~cm}$ apart and seeds were spaced $10 \mathrm{~cm}$ writhen rows.

Fayoum J. Agric. Res. \& Dev., Vol. 31, No.1, January, 2017 
Data were recorded on 25 individual guarded plants for $\mathrm{P}_{1}, \mathrm{P}_{2}$ or $\mathrm{F}_{1}$ and 60 plants for each of $\mathrm{Bc}_{1}$ or $\mathrm{Bc}_{2}$ and 75 plants for $\mathrm{F}_{2}$ in each replicate for the studied characters, i.e., number of days to heading, number of days to maturity, number of spikes/plant, number of grains/ spike, 100-kernel weight (g) and grain yield/plant (g). All recommended field practices for wheat production were applied in all growing seasons.

Fertilizers and irrigation all recommended package was applied, recommended dose of NP was applied according to treatments as $70 \mathrm{Kg} \mathrm{P}_{2} \mathrm{O}_{5}$ $\mathrm{ha}^{-1}$ during preparation and $175 \mathrm{Kg}$ Nitrogen $\mathrm{ha}^{-1}$ was applied Ammonia injection in soil after final land preparation and before sowing. Six irrigations were applied at 20 days intervals.

Weed control the crop was maintained with weed free using chemical material. Broad leaf weeds were controlled by spraying of Derby $175 \%$ SC after 30 days from planting.

\section{Statistical and genetic analysis}

Type of gene effects estimated according to Gamble (1962) the six parameter's model was applied to separate out the components of genetivc variance to its mean effects $m=$ mean $F_{2}$, additive (a), dominance (d), additive $\mathrm{x}$ additive ( $\mathrm{a}$ a), additive $\mathrm{x}$ dominance $(\mathrm{a} d)$, dominance $\mathrm{x}$ dominance $(\mathrm{d} d$ ). The amount of heterosis was expressed as the percentage deviation of $F_{1}$ mean performance forms the mid- parent values. Inbreeding depression was calculated as the difference between the $\mathrm{F} 1$ and $\mathrm{F}_{2}$ means expressed as percentage of the $F_{1}$ mean, Wynn et al (1970). And $S$-E for inbreeding depression was estimated as following $F_{1}-F_{2}=\left(V_{1}+V_{2}\right)^{1 / 2}$.

Simth ,(1952), proposed the following equation to determine potence ratio, which can defined as follows:

$$
\text { Potence ratio }=\frac{\text { F1 }- \text { MP }}{(\mathbf{P 1}-\mathbf{P 2}) 1 / 2}
$$

\section{Mean Performances}

Generation means of the six populations $\left(\mathrm{P}_{1}, \mathrm{P}_{2}, \mathrm{~F}_{1}, \mathrm{~F}_{2}, \mathrm{BC}_{1}\right.$ and $\left.\mathrm{BC}_{2}\right)$ of the two wheat crosses for yield and other traits are presented in (Table 2). The results of generation means for all studied traits in the two crosses revealed significant differences among all six generations, indicating the presence of genetic variability for these traits in the studied materials. In first cross the $\mathrm{F}_{1}$ population was the earliest one comparing the two parents, were higher than the highest parent for1000 kernels weight (49.85g). However, $\mathrm{P}_{2}$ was the best one for number of spike per plant and number of kernels per spike (22.67 and 87.43) respectively, but $\mathrm{P}_{1}$ gave the highest value $(51.00 \mathrm{~g})$ for grain yield per plant.

Fayoum J. Agric. Res. \& Dev., Vol. 31, No.1, January, 2017 
M. M. Mohamed, et al.,

Table (2): Mean performance for the six generations for all studied traits in the two studied crosses.

\begin{tabular}{|c|c|c|c|c|c|c|c|}
\hline Crosses & $\begin{array}{c}\text { Traits } \\
\text { generation }\end{array}$ & DH & DM & NS Plant ${ }^{-1}$ & NG spike ${ }^{-1}$ & 1000-KW & GY plant ${ }^{-1}(g)$ \\
\hline \multirow{6}{*}{ Cross 1} & P1 & 106.00 & 154.00 & 20.77 & 72.97 & 40.95 & 51.00 \\
\hline & $\mathrm{P} 2$ & 117.33 & 153.67 & 22.67 & 87.43 & 31.37 & 48.37 \\
\hline & F1 & 103.67 & 148.00 & 18.02 & 74.70 & 49.85 & 45.87 \\
\hline & F2 & 105.00 & 154.33 & 16.38 & 59.00 & 43.99 & 49.40 \\
\hline & $\mathrm{BC} 1$ & 105.33 & 149.33 & 18.21 & 74.85 & 42.95 & 46.67 \\
\hline & $\mathrm{BC} 2$ & 106.67 & 154.33 & 14.20 & 69.62 & 43.26 & 50.56 \\
\hline \multirow{6}{*}{ Cross II } & $\mathrm{P} 1$ & 103.00 & 155.00 & 19.42 & 69.93 & 32.91 & 45.10 \\
\hline & $\mathrm{P} 2$ & 118.67 & 154.67 & 20.87 & 70.02 & 38.42 & 53.08 \\
\hline & F1 & 106.33 & 154.33 & 19.87 & 72.87 & 40.25 & 43.75 \\
\hline & F2 & 104.00 & 154.00 & 19.40 & 63.66 & 39.88 & 43.42 \\
\hline & $\mathrm{BC} 1$ & 104.67 & 155.00 & 21.28 & 87.86 & 39.02 & 52.10 \\
\hline & $\mathrm{BC} 2$ & 107.00 & 156.00 & 23.03 & 84.23 & 40.51 & 57.50 \\
\hline
\end{tabular}

In second cross $\mathrm{P} 1$ which recorded (103 days) was the earliest one for days to heading, but $\mathrm{F}_{2}$ which recorded (154 days) was the earliest one for days to maturity. The data from (Table 2) showed that, $\mathrm{BC}_{2}$ go one better than two parents for number of spike per plant (23.03), 1000 kernels weight (40.51g) and grain yield per plant $(57.50 \mathrm{~g})$, on the other hand $\mathrm{BC} 1$ gave the highest number for number of grain per spike.

\section{Gene Effects}

The estimates of the six parameters, i.e. additive (d), dominance (h), additive $x$ additive (i), additive $x$ dominance $(j)$ and dominance $x$ dominance (I) and means (m) are presented in (Table 3 ). The mean effects were highly significant for all studied traits in the two crosses, indicating that these traits are quantitatively inherited. The additive gene effects were negative and highly significant for all traits under study except number of grains per spike is positive and highly significant with two crosses and number of spike per plant for first cross. These results indicated that the potentiality of improving the performance of these traits using the pedigree selection program may be more effective, Abul-Nass et. al. (1993), Hendawy (2003) and Mohamed A. I.Khaled(2013).

In autogamous crops, i.e., wheat and barley, the breeder is usually aiming to isolate parental combinations that are likely to produce desirable homozygous segregates. The utility of attempts in identifying such pure lines is facilitated by the preponderance of additive genetic effects in selfpollinating crops,(Joshi and Dhawan,1966).

Fayoum J. Agric. Res. \& Dev., Vol. 31, No.1, January, 2017 
STUDY OF INHERITANCE FOR YIELD AND SOME. 54

Table(3): Parameters of gene effects relating to studied traits in the two crosses.

\begin{tabular}{|c|c|c|c|c|c|c|c|}
\hline \multirow{3}{*}{ Traits } & \multirow{3}{*}{ Cross } & \multicolumn{6}{|c|}{ Gene action six parameters (Gamble procedure) } \\
\hline & & $\begin{array}{l}\text { Main } \\
\text { effect }\end{array}$ & Additive & Dominance & Add. $x$ Add. & Add. $x$ Dom. & Dom.x Dom. \\
\hline & & $(\mathbf{m})$ & (a) & (d) & (aa) & (ad) & (dd) \\
\hline \multirow{2}{*}{$\begin{array}{l}\text { Days to } \\
\text { heading }\end{array}$} & $\mathrm{I}$ & $105 * *$ & $-1.34 * *$ & $-53.95 * *$ & $4 * *$ & $4.325 * *$ & $2.66 * *$ \\
\hline & II & $104 * *$ & $-2.33 * *$ & $2.48 * *$ & $7.34 * *$ & $5.51 * *$ & $3.65 * *$ \\
\hline \multirow{2}{*}{$\begin{array}{c}\text { Days to } \\
\text { maturity }\end{array}$} & $\mathrm{I}$ & $154.33 * *$ & $-5 * *$ & $-15.83 * *$ & $-10 * *$ & $-5.16 * *$ & $6.34 * *$ \\
\hline & II & $154 * *$ & $-1 * *$ & $5.5 * *$ & $6 * *$ & $-1.17 * *$ & $-9.67 * *$ \\
\hline \multirow{2}{*}{$\begin{array}{c}\text { No. of spikes } \\
\text { plant }^{-1}\end{array}$} & $\mathrm{I}$ & $16.38 * *$ & $4.01 * *$ & $-4.4 * *$ & $-0.700 * *$ & $4.96 * *$ & $15.36 * *$ \\
\hline & II & $19.4 * *$ & $-2.02 * *$ & $11.33 * *$ & $11.56^{* *}$ & $-1.34 * *$ & $-20.78 * *$ \\
\hline \multirow{2}{*}{$\begin{array}{c}\text { No. of grains } \\
\text { spike }^{-1}\end{array}$} & $\mathrm{I}$ & $59 * *$ & $5.22 * *$ & $47.44 * *$ & $52.94 * *$ & $12.46^{* *}$ & $-32.08 * *$ \\
\hline & II & $63.66 * *$ & $3.36 * *$ & $92.44 * *$ & $89.54 * *$ & $3.67 * *$ & $-148.03 * *$ \\
\hline \multirow{2}{*}{$\begin{array}{c}\text { 1000-kernel } \\
\text { weight }\end{array}$} & I & $43.99 * *$ & $-0.30 * *$ & $10.15 * *$ & $-3.53 * *$ & $-5.1 * *$ & $3.14 * *$ \\
\hline & II & $39.88 * *$ & $-1.49 * *$ & $4.12 * *$ & $-0.46^{* *}$ & $1.27 * *$ & $-6.77 * *$ \\
\hline \multirow{2}{*}{$\begin{array}{c}\text { Grain yield } \\
\text { plant }^{-1}\end{array}$} & I & $49.4 * *$ & $-3.89 * *$ & $-6.95 * *$ & $-3.13 * *$ & $-5.20 * *$ & $-0.20 * *$ \\
\hline & II & $43.42 * *$ & $-5.4^{* *}$ & $40.18^{* *}$ & $45.52 * *$ & $-1.41 * *$ & $-79.04 * *$ \\
\hline
\end{tabular}

The estimates of dominance (d) effects were significant for all studied traits. The estimates of dominance were positive and highly significant for days to heading, days to maturity, number of spike per plant, grain yield per plant in second cross, also number of grains per spike and 1000 kernels weight in two crosses. On the other hand the estimates of dominance were negative and highly significant for days to heading, days to maturity, number of spike per plant and grain yield per plant in first cross only. The dominance gene effect was higher than additive gene effect for all studied traits in the two crosses indicating predominant role of dominant component of gene action in inheritance of these traits, so the selection for these traits should be delayed to later generation when dominant effect is diminished. These results Similar results obtained by Novoselovic et al (2004) and E.I. Zaazaa and ElHashash (2012).

On the other hand, significance of additive (a) and dominance (d) components indicated that both additive and dominance gene effects were important in the inheritance of these traits. Also, selecting desirable characters may be practiced in the early generations but it would be effective in the late ones. Similar results were obtained by Hendawy (2003), Moussa (2010) and Mohamed A. I.Khaled(2013).

Estimates of epistatic gene effects, additive $\mathrm{x}$ additive (aa), additive $\mathrm{x}$ dominance (ad) and dominance $\mathrm{x}$ dominance (dd) are presented in Table (3). Significant estimates of epistatic gene effects for one or more of these three types of epistatic gene effects in the two crosses for all studied traits were detected. Additive $\mathrm{x}$ additive (aa) gene effects were positive and highly significant in days to heading and number of grains per spike for two crosses, also days to maturity, number of spike per plant and grain yield per plant in

Fayoum J. Agric. Res. \& Dev., Vol. 31, No.1, January, 2017 
second cross. Meanwhile, it was negative and significant in case of days to maturity, number of spike per plant, 1000 kernels weight and grain yield per plant in first cross and 1000 kernels weight in second cross.

Data concerning the epistatic gene effects, additive $\mathrm{x}$ dominance (ad) revealed different positive and highly significant estimates in days to heading, number of spike per plant and number of grains per spike in first cross. However, days to heading, 1000 kernels weight and number of grains per spike in second cross. Meanwhile, it was negative and highly significant in other traits.

The dominance $\mathrm{x}$ dominance (dd) gene effect differed according to crosses and characters, positive and highly significant estimates in two crosses for days to heading. But negative and highly significant in number of grains per plant and grain yield per plant in two crosses, however, days to maturity, number of spike per plant and 1000 kernels weight were highly significant estimates positive for first cross and negative for second cross. The study further revealed that epistatic gene effects were as important as additive and dominance gene effects for most of the traits. Thus, the system of inbreeding employed in exploiting any character depends on the gene action involved in its expression for predicted gain in selection progress (Abul-Naas et al 1993) Mohamed A. I.Khaled(2013).

\section{Heterosis}

In self-pollinated crops, such as wheat, plant breeders have been investigating the possibility of developing hybrid cultivars. Thus, the utilization of heterosis in various crops through the world has tremendously increased the production either for human food or livestock feed. Heterosis is a complex phenomenon which depends on the balance of different combinations of genotypic effect as well as the distribution of plus and minus alleles in the parents. Data presented in (Table 4) showed heterotic effect calculated as percentage over mid parents for studied traits in the two crosses. Highly significant heterotic effect positive was found between crosses for 1000 kernels weight in two crosses and number of grains per spike in second cross.

Inbreeding depression

Inbreeding depression could be defined as the reduction of values of characters from $F_{1}$ to $F_{2}$ generations. This reduction may be due to the change of genetic constitution and decrease heterozygosity due to inbreeding. The results of estimation of inbreeding depression are presented in (Table 4). Regarding both days to heading and days to maturity characters, all two studies crosses showed highly significant negative with first cross and positive with second cross. In general first cross was highly significant negative, but in second cross grain yield per plant, 1000 kernels weight and number of grains per spike was nonsignificant.

Fayoum J. Agric. Res. \& Dev., Vol. 31, No.1, January, 2017 
STUDY OF INHERITANCE FOR YIELD AND SOME. 56

Table (4): Heterosis, potance ratio and Inbreading, depression of the mean for the studied traits in the two crosses.

\begin{tabular}{|c|c|c|c|c|c|c|c|}
\hline Crosses & Parameters & DH & DM & NS Plant & NG spike & 1000-KW & GY plant g \\
\hline Cross 1 & $\begin{array}{c}\text { heterosis } \\
\text { MP\% }\end{array}$ & -7.16 & -3.79 & -17.03 & -6.86 & $37.86^{* *}$ & -7.68 \\
\hline & $\begin{array}{c}\text { Inbreading } \\
\text { depression }\end{array}$ & $-1.28^{* *}$ & $-4.28 * *$ & $9.1 * *$ & $21.02 * *$ & $11.75^{* *}$ & $-7.619 * *$ \\
\hline & potancel ratio & -1.41 & -35.36 & -3.89 & -0.76 & 2.86 & -2.90 \\
\hline Cross II & $\begin{array}{c}\text { heterosis } \\
\text { MP\% }\end{array}$ & -4.06 & -0.33 & -1.14 & $4.14 * *$ & $12.86^{* *}$ & -10.88 \\
\hline & $\begin{array}{c}\text { Inbreading } \\
\text { depression }\end{array}$ & $2.19 * *$ & $0.21^{* *}$ & $2.36^{* *}$ & 12.64 & 0.92 & 0.75 \\
\hline & potancel ratio & -0.06 & -3.06 & -0.34 & 64.33 & 1.66 & -1.34 \\
\hline
\end{tabular}

\section{Potence ratio:}

In two crosses, regarding potance ratio value were more than unity for all traits under study except number of grains per spike with first cross and days to heading in second cross. When the potence ratio values were more than unity this indicating that over dominance was important in the inheritance of this traits in theses crosses. Also, the potance ratio value were less than unity this indicating that partial dominance of this traits. This result was completely in agreement with those obtained by Mann and Sharma (1995), Al-Kaddoussi (1996), Awaad (2002) and Hagras (1999).

\section{REFERENCES}

Abul - Nass, A.A., M.A. Mahrous and A.A. El Hoseary 1993. Genetical studies on grain yield and some of its components in barley (Hordeum valgar L.) Egypt. J. Agron., 18 (1-2) 33-46.

Al-Kaddoussi, A.R. (1996). Using genetic components for predicting new recombinant lines crosses of Egyptian wheat (Triticum aestivum, 1.) Zagazig J. Agric. Res, 23: 463-475.

Awaad, H. A. (2002). Genetic analysis, response to selection and production of new recombinant lines in bread wheat. Zagazig J. Agric. Res. 29 (5): 1343-1365.

Zaazaa E.I., M.A. Hager and El-Hashash E.F. (2012). Genetical Analysis of Some Quantitative Traits in Wheat Using Six Parameters Genetic Model. American-Eurasian J. Agric. \& Environ. Sci., 12 (4): 456-462.

Faridi, H. and Faubion, J. M. (1995). Wheat end-uses around the world. American association of cereal chemists. Stpuel, Minnesota, USA

Gamble, E.E. 1962. Gene effects in corn (Zea mays L.) separation and relative importance of gene effects for yield. Canadian J. Plant Sci., 42: 339348.

Hagras, A.A.T. (1999). Inheritance of some quantitative characters in bread wheat. M.Sc. Thesis, Zagazig Univ. Egyptr.

Fayoum J. Agric. Res. \& Dev., Vol. 31, No.1, January, 2017 
M. M. Mohamed, et al.,

Hendawy. H. 2003. Gentic architecture of yield and its components and some other agronomic traits in bread wheat. Menufiya J. of Agric. Res., 28 (1) : 71-86.

Joshi., A.B. and N.L. Dhawan 1966. Gentic improvement in yield and special reference to self -fertilized crop. India J. Genet and plant bread., 26101.

Khaled M. A. I. (2013). Genetic system controlling the yield and its components in three bread wheat (Triticum aestivum, 1.) Crosses. Egypt. J. Agric. Res., 91(2), 641:653.

Mousaa, A.M. 2010. Estimation of epistasis, additive and dominance variation in certain bread wheat (Triticum aestivum L.) crosses. J. plant prod., Mansoura Univ, (12): 1707-1719.

Mann, M.S. and S.N. Sharma, 1995. Genetic of yield, harvest index and related components in durum wheat. Crop Improve., 22:38-44.

Novoselovic, D.; M. Baric; G. Drezner; J. Gunjaca and A.Lalic (2004). Quantitative inheritance of some wheat plant traits. Genetics and Molecular Biology. 2004. 27; 1, 92-98. 20 ref. (C.F. computer Inter. Agric. Cent. For Information Service).

Smith. H. H. (1952). Fixing transgrssive vigor in Nicotiana rustica. In heterosis, low State. Coll. Press, Ames. Lowa, USA.

Wynn, J.C., T.A.Emery and P.W.Rice 1970. Combining ability in archis hypogeaen. Field performance of hybrids. Cropsci., 10 713-715.

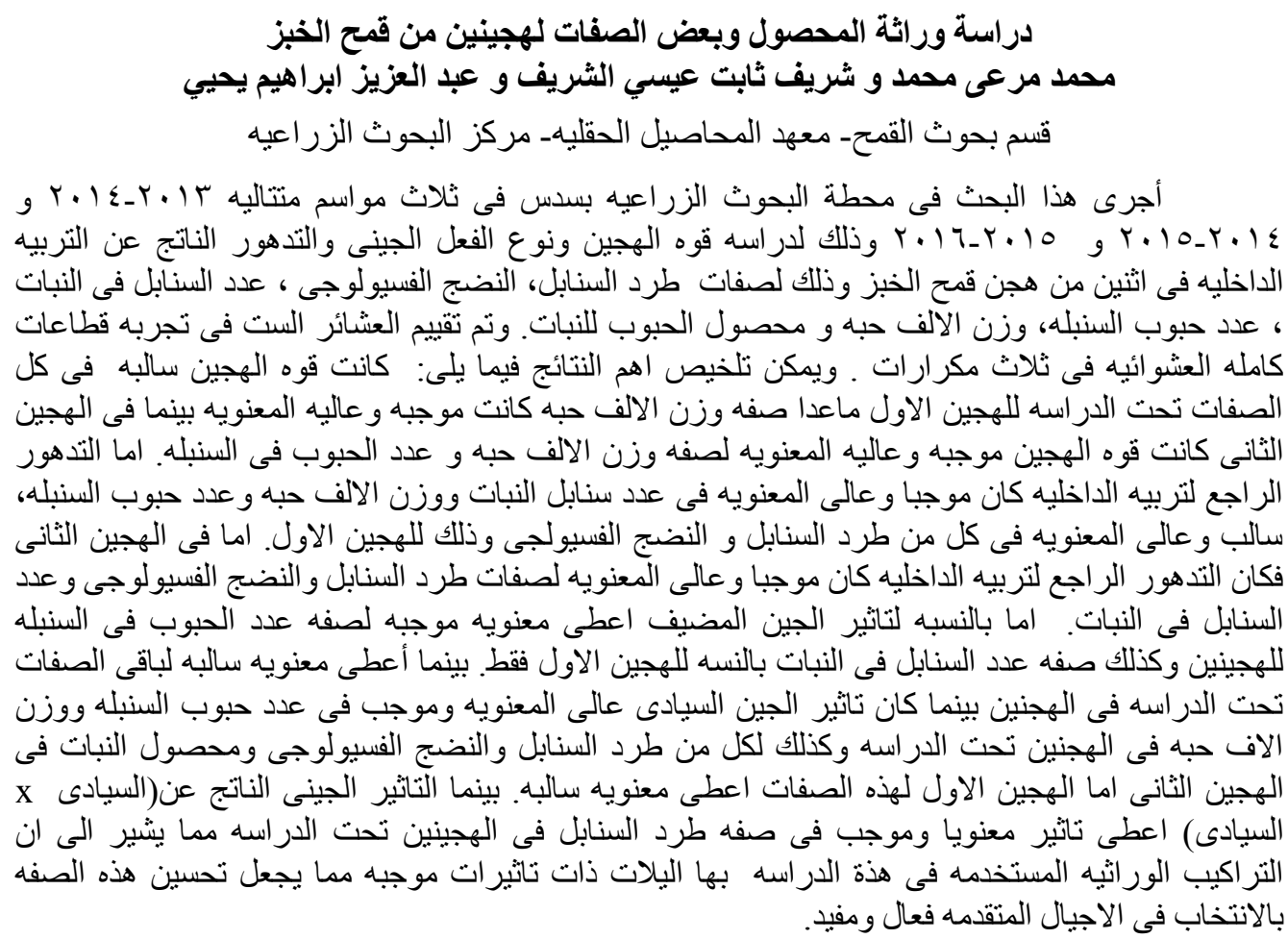

Fayoum J. Agric. Res. \& Dev., Vol. 31, No.1, January, 2017 